https://doi.org/10.15407/frg2020.02.128

UDC 57.085.23:577.214.625:633.19

\title{
PCR ANALYSES OF FIRST-GENERATION PLANTS OF AMARANTHUS CAUDATUS L. AFTER «FLORAL-DIP» GENETIC TRANSFORMATION
}

\author{
O.M. YAROSHKO ${ }^{1}$, B.V. MORGUN ${ }^{1,2}$, L.G. VELYKOZHON ${ }^{1,2}$, A. GAJDOŠOVA ${ }^{3}$, \\ O.L. ANDRUSHENKO ${ }^{4}$, M.V. KUCHUK ${ }^{1}$
}

${ }^{1}$ Institute of Cell Biology and Genetic Engineering, National Academy of Sciences of Ukraine

148 Akademika Zabolotnoho St., Kyiv, 03143, Ukraine

90tigeryaroshko90@gmail.com

${ }^{2}$ Institute of Plant Physiology and Genetics, National Academy of Sciences of

Ukraine

31/17 Vasylkivska St., Kyiv, 03022, Ukraine

${ }^{3}$ Institute of Plant Genetics and Biotechnology PSBC Slovak Academy of Sciences

2 Akademická St., Nitra, 95007, Slovak Republic

${ }^{4}$ M.M. Gryshko National Botanical Garden, National Academy of Sciences of

Ukraine, Kyiv, Ukraine

1 Tymiriazevska St., 01014, Kyiv, Ukraine

Amaranth is the $\mathrm{C}_{4}$-plant which used in various industries and is a promising object for genetic transformation. After «floral-dip» transformation of Helios and Karmin cultivars of Amaranthus caudatus L. using Agrobacterium rhizogenes A4 strain and A. tumefaciens GV3101 strain, transformed plants of the first generation were obtained. Gene vectors pCB125 and pCB131 contained a bar gene imparting resistance to commercial herbicide Basta. Seeds of Helios and Karmin cultivars of amaranth were obtained. The T-DNA transmission of strains A4 (pCB131) and GV3101 (pCB125) was evaluated by herbicide selection of amaranth plants. Tolerant plants were obtained for both cultivars after spraying with the herbicide. The percentage of $A$. $\times$ caudatus cv. Helios (vector pCB125) plants tolerant to the effect of the herbicide (160 mg/l) was $4.05 \%$, cv. Karmin (vector pCB125) - was $2.4 \%$. The percentage of tolerant $A$. $\times$ caudatus cv. Karmin (vector pCB131) plants was $0.6 \%$. The transgene presence of pCB125 gene vector (A. tumefaciens strain GV3101) and pCB131 vector (A. rhizogenes A4 strain) in amaranth tissue was analyzed. Integration of the bar gene and nos terminator in plants was confirmed by PCR analysis. The percentage of bar-positive plants for cv. Helios (gene vector pCB125) was $0.6 \%$ of the total initial quantity of plants (12 positive plants of 2,000 ), and for cv. Karmin (gene vector pCB131) was $0.1 \%$ of the total initial quantity of plants (2 plants of 2,000). The percentage of nos terminator-positive plants for cv. Helios was $0.15 \%$ of the total initial quantity of plants (3 plants of 2,000).

Key words: Amaranthus caudatus L., Agrobacterium, transformation, genetically modified plants.

Citation: Yaroshko O.M., Morgun B.V., Velykozhon L.G., Gajdošova A., Andrushenko O.L., Kuchuk M.V. PCR analyses of firstgeneration plants of Amaranthus caudatus L. after «floral-dip» genetic transformation. Fiziol. rast. genet., 2020, 52, No. 2, pp. 128-139. https://doi.org/10.15407/frg2020.02.128 
Amaranth plants are used in the food industry, medicine, cosmetics and agriculture. They serve as a source of biologically active substances, the most valuable of which are squalene and amarantin. Squalene has anticancer and wound healing properties while amarantin has an antioxidant activity [1, 2]. The seeds of the Amaranthus species are rich in methionin and lysine amino acids. Biologically valuable substances can be obtained by using biotechnological methods. Plants that synthesize new alien substances may potentially be obtained through genetic transformation by using an Agrobacterium vector. However, there are relatively few works devoted to the transformation of amaranth. Transgenic roots were obtained for Amaranthus tricolor L. [3] and A. spinosus L. [4].

Transgenic plants were obtained for $A$. hypochondriacus L. and $A$. tricolor [5, 6], A. retroflexus L., A. viridis L., A. cruentus L. (A. paniculatus L.) [7]. No additional information is available about the transformation of $A$. caudatus, which varieties are also used in agriculture [8]. In our previous work, we obtained transgenic plants of Amaranthus $\times$ caudatus cv. Kremovii rannii, Karmin, Helios, Rushnichok; A. caudatus $\times$ A. paniculatus L. - cv. Sterkch with incorporated gus and bar genes of the pCBV19 gene vector of A. tumefaciens $[8,9]$. In this article, the results of the transformation of amaranth varieties with other genetic constructs and other bacterial strains are considered.

The aim of this work was to analyze the presence of nos-terminator sequence and bar transgene from A. tumefaciens GV3101 (pCB125) and A. rhizogenes A4 (pCB131) strains in tissue of the first generation of transgenic amaranth plants.

\section{Materials and methods}

The cultivars Helios and Karmin of the Amaranthus $\times$ caudatus were used in the work. The seeds were obtained from the M.M. Grishko National Botanical Garden, NAS of Ukraine.

Karmin is an early ripening cultivar. The average height of plants is $190-200 \mathrm{~cm}$ and the inflorescence color is purple. The green-purple leaves are oval-ovate. The maturity of seeds occurs 100-110 days from the beginning of the growing season. The colour of seeds is milk-white and the average weight of $1,000 \mathrm{pc}$. is $0.8 \mathrm{~g}$. The grain yield is $80-90 \mathrm{~kg} / \mathrm{ha}$, and the biomass - 1,100-1,110 kg/ha. The cultivar was included in the State Register of Varieties of Ukraine in 2000. The originator of the variety, patent applicant and owner is the M.M. Grishko National Botanical Garden, NAS of Ukraine [10].

Helios is an early ripening cultivar. The growing season is 105 days. Plant height is $150-170 \mathrm{~cm}$. The leaves are light green with orange streaks. The inflorescence has a light golden color in the ripening phase. The seed is milk-white. Grain yield is $15-30 \mathrm{~kg} / \mathrm{ha}$, and biomass - 1,500 kg/ha. When tested in the Kyiv region, this variety showed the highest content of oil and squalene compared to other local amaranth cultivars. The cultivar was included in the State Register of Varieties of Ukraine in 2010 [11].

These cultivars were chosen because they are early ripening, mature in the steppe and forest-steppe climatic zones of Ukraine, and have compact inflorescences mainly only at the top of the stems, which facilitates the iso- 


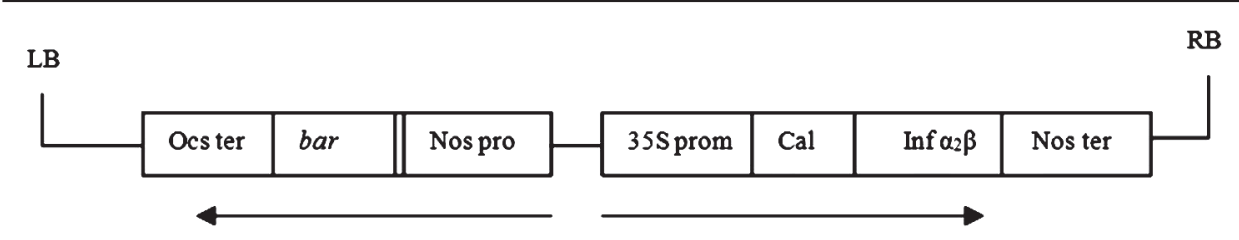

Fig. 1. Schematic representation of the T-DNA site of the pCB125 vector. LB - left border sequence, RB - right border sequence, Nos pro - nopaline synthase promoter, Nos ter - nopaline synthase terminator, $35 \mathrm{~S}$ prom - promoter of cauliflower mosaic virus gene (CaMV), bar - bar gene (phosphinothricin acetate transferase gene), Ocs ter - octopine synthase terminator, inf $\alpha 2 \beta-$ human interferon $\alpha 2 \beta$ gene, Cal - fused with plant $(N$. plumbagenifolia L.) calreticulin apoplastic targeting signal

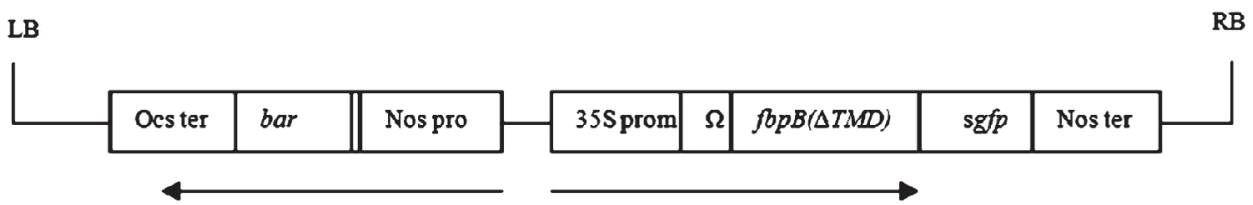

Fig. 2. Schematic representation of the T-DNA site of the pCB131 vector. LB - left border sequence, RB - right border sequence; bar - bar gene (phosphinothricin acetate transferase gene), Nos pro - nopaline synthase promoter, Nos ter - nopaline synthase terminator, 35S prom - promoter of cauliflower mosaic virus gene (CaMV), Ocs ter - octopine synthase terminator, $f b p \mathrm{~B}(\Delta \mathrm{TMD})$ - gene, coding tuberculosis antigen $\mathrm{Ag} 85 \mathrm{~B}$; $s g f p-$ superfolder green fluorescent protein gene, $\Omega-$ regulatory sequence enhancer

lation of inflorescences in the flowering phase, as well as the collection of mature seeds.

The vectors pCB125 of $A$. tumefaciens and pCB131 of $A$. rhizogenes A4 (Fig. 1 and 2) allowed us to check and evaluate the function of heterologous DNA sequences in amaranth plants. The bar gene is responsible for herbicide resistance. Nos terminaror is termination sequence of the nopaline synthase gene, the function of this sequence is to signal the termination of the gene expression.

Transformation of plants. The Helios and Karmin cultivars of $A . \times c a u-$ datus were transformed according to the «floral-dip» method [12]. The peculiarities of the transformation process and the detailed description of all the stages of transformation were described in our previous article [9]. The mature seeds $\left(\mathrm{T}_{1}\right)$ were harvested and stored according to Curtis [13, 14 ].

Herbicide selection. To evaluate the transfer of T-DNA sequence of Agrobacterium rhizogenes A4 gene vector pCB131 and A. tumefaciens GV3101 pCB125 gene vector in amaranth tissues, we carried out herbicide selection (the Basta $\left.{ }^{(}\right)$herbicide, Bayer CropScience AG, Germany). For this purpose, the lowest lethal concentration of Basta herbicide on amaranth seedlings was identified in our previous experiments $(160 \mathrm{mg} / \mathrm{l}$ of herbicide) [8].

To screen for the presence of bar gene, 2,000 seeds obtained from «floral-dipped» plants and 200 seeds obtained from control plants (grown without Agrobacterium treatment) were sown separately. Seeds were grown in plastic pots with soil in greenhouse conditions $\left(22-26{ }^{\circ} \mathrm{C}, 14\right.$-hour light period, illumination 3,000-4,500 lx). The seedlings obtained from «floraldipped» and control plant seeds were treated at the age of two weeks with 
the herbicide in a concentration of $160 \mathrm{mg} / \mathrm{l}$ (screening for the resistant plants possessing a bar gene). After performing these stages of the experiment, a statistical analysis of the bar-positive plants was carried out.

DNA purification. Genomic DNA was isolated by the CTAB method [15]. For the PCR analysis, we used a reaction mixture of the following composition: $10.25 \mu \mathrm{l}$ Milli-Q $\mathrm{H}_{2} \mathrm{O}, 2 \mu \mathrm{l}$ 10x Reaction buffer B (Solis BioDyne), $2 \mu 11 \mathrm{mM}$ cresol $60 \%$ sucrose (Solis BioDyne), $1.6 \mu \mathrm{l} 25 \mathrm{mM}$ $\mathrm{MgCl}_{2}$ (Solis BioDyne), $0.5 \mu \mathrm{l}$ of forward and $0.5 \mu \mathrm{l}$ of reverse $(10 \mu \mathrm{l})$ primers, $2 \mu \mathrm{l} 2 \mathrm{mM}$ deoxyribonucleotide triphosphate (dNTP) (Thermo Fisher Scientific), $0.15 \mu \mathrm{l} 5 \mathrm{U} / \mu \mathrm{l}$ FirePol DNA Polymerase (Solis BioDyne), $1.5 \mu \mathrm{l}$ DNA (20-30 ng/ml DNA). The volume of the reaction mixture was $20 \mu \mathrm{l}$. The amplification reaction was carried out in thermal cyclers - Arctic Thermal Cycler (Thermo Fisher Scientific) and Mastercycler gradient (Eppendorf).

PCR analysis (polymerase chain reaction). To identify the bar gene, primers 5'-ACA TCG AGA CAA GCA CGG TC-3' and 5'-GCC AGA AAC CCA CGT CAT GC-3' (Metabion, Germany) were used [16]. Amplification conditions: initial denaturation at $94{ }^{\circ} \mathrm{C}$ for $4 \mathrm{~min}$, denaturation at $94{ }^{\circ} \mathrm{C}$ for $30 \mathrm{~s}$, annealing at $65{ }^{\circ} \mathrm{C}$ for $30 \mathrm{~s}$, extension at $72{ }^{\circ} \mathrm{C}$ for $1 \mathrm{~min}$ for the first cycle followed by 34 cycles each. Final polymerization was at $72{ }^{\circ} \mathrm{C}$ for $5 \mathrm{~min}$. The size of the expected amplicon was 405 base pairs (bp).

To identify the NOS terminator, primers 5'-GAA TCC TGT TGC CGG TCT TG-3' and 5'-GCG GGA CTC TAA TCA TAA AAA CC-3' were used [17]. Amplification conditions: initial denaturation at $94{ }^{\circ} \mathrm{C}$ for $4 \mathrm{~min}$, denaturation at $94^{\circ} \mathrm{C}$ for $30 \mathrm{~s}$, annealing at $57^{\circ} \mathrm{C}$ for $1 \mathrm{~min}$, extension at $72{ }^{\circ} \mathrm{C}$ for $30 \mathrm{~s}$, for the first cycle followed by 35 cycles each. Final polymerization was at $72{ }^{\circ} \mathrm{C}$ for $5 \mathrm{~min}$. The size of the expected amplicon was 125 base pairs (bp).

To identify the $\beta$-tubulin gene, primers 5 '-ATG TGG GAT GCC AAG AAC ATG ATG TG-3' and 5'-TCC ACT CCA CAA AGT AGG AAG AGT TCT-3' were used [18, 19]. Amplification conditions: initial denaturation at $94{ }^{\circ} \mathrm{C}$ for $3 \mathrm{~min}$, denaturation at $94{ }^{\circ} \mathrm{C}$ for $30 \mathrm{~s}$, annealing at $60{ }^{\circ} \mathrm{C}$ for $30 \mathrm{~s}$, extension at $72{ }^{\circ} \mathrm{C}$ for $20 \mathrm{~s}$, for the first cycle followed by 34 cycles each. Final polymerization was at $72{ }^{\circ} \mathrm{C}$ for $5 \mathrm{~min}$. The size of the expected amplicon was 157 base pairs (bp).

To identify the virC gene, primers 5'-ATC ATT TGT AGC GAC T-3' and 5'-AGC TCA AAC CTG CTT C-3' were used [20]. Amplification conditions: initial denaturation at $94{ }^{\circ} \mathrm{C}$ for $3 \mathrm{~min}$, denaturation at $94{ }^{\circ} \mathrm{C}$ for $30 \mathrm{~s}$, annealing at $55^{\circ} \mathrm{C}$ for $47 \mathrm{~s}$, extension at $72{ }^{\circ} \mathrm{C}$ for $30 \mathrm{~s}$, for the first cycle followed by 40 cycles each. Final polymerization was at $72{ }^{\circ} \mathrm{C}$ for 5 min. The size of the expected amplicon was 720 base pairs (bp).

GeneRulerTM DNA Ladder Mix (Thermo Fisher Scientific) molecular weight markers were used to determine the amplification products.

DNA electrophoresis. Separation of amplified products was conducted by horizontal electrophoresis. The electrophoresis was performed in agarose gel containing LB-buffer with $1.2 \%$ agarose and $5 \mu \mathrm{g} / \mathrm{ml}$ ethidium bromide (for identification of bar, vir $C$ genes) and agarose gel containing LBbuffer with $0.8 \%$ agarose with $5 \mu \mathrm{g} / \mathrm{ml}$ etidium bromide (for identification 
of nos terminator and $\beta$-tubulin gene). For sample analysis, $100 \mathrm{ng}$ of total plant DNA, previously dissolved in TE buffer $\mathrm{pH}$ 7.6, was used. Electrophoresis was performed under $5 \mathrm{~V} / \mathrm{cm}$ for $45 \mathrm{~min}$. A UV light source and a digital Canon camera were used to obtain the gel image. The resulting image was processed using a GIMP graphical editor.

\section{Results and discussion}

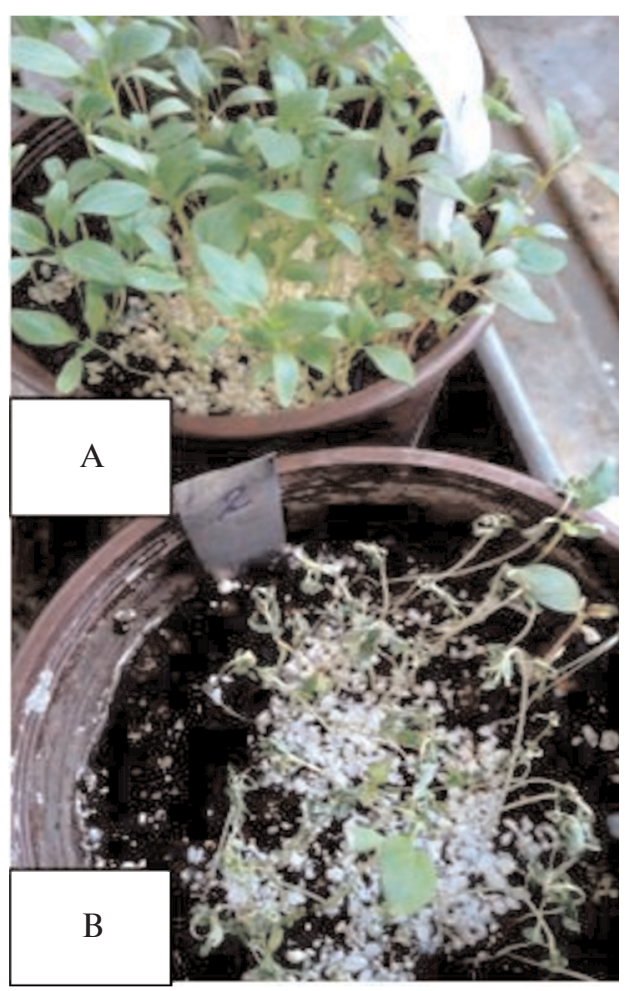

Fig. 3. The effect of Basta herbicide on the seedlings of non-transformed Amaranthus caudatus cv. Helios: A $-0 \mathrm{mg} / \mathrm{l}$ (control); B - plants sprayed with herbicide $(160 \mathrm{mg} / \mathrm{l})$ after 7 days
Usually, advances in plant genetic engineering concern the optimization of agrotransformation methods and factors influencing the transfer of a selective marker and/or reporter gene via Agrobacterium to the plant cell. This is followed by the alien gene's integration in the recipient plant genome and subsequently its expression and stability in the transgenic plants. Considering the useful properties of Amaranthus plants, the present work was conducted with the aim of identifying the functioning of the pCB131 gene vectors of $A$. rhizogenes and the pCB125 gene vector of $A$. tumefaciens in amaranth tissues and obtaining transgenic amaranth plants after genetic transformation using the GV3101 strain of A. tumefaciens (pCB125) and $\mathrm{A} 4$ strain of $A$. rhizogenes (pCB131).

Herbicide selection. Due to possible escape rates (obtaining false positive results) of non-transformed plants, it was necessary to accept a compromise regarding the survival percentages of the presumably transformed plants and the non-transformed plants. That is why the first step of the experiment was to determine the lowest lethal concentration of herbicide on non-transformed amaranth seedlings. The lowest lethal concentration of herbicide was $160 \mathrm{mg} / \mathrm{l}$ (Fig. 3).

This concentration of herbicide $(160 \mathrm{mg} / \mathrm{l})$ was lethal for $100 \%$ of non-transformed Amaranthus plants, but a certain quantity of presumably transformed plants remained alive which may indicate they were resistant and it can be assumed that they had a built-in bar gene [21]. For the first time, we have obtained transgenic seeds for the cultivars of $A$. caudatus.

After spraying with herbicide, resistant plants were obtained for two cultivars: Helios and Karmin (Fig. 4). The percentage of $A$. $\times$ caudatus cv. Helios plants (with vector pCB125) tolerant to the effect of the herbicide 

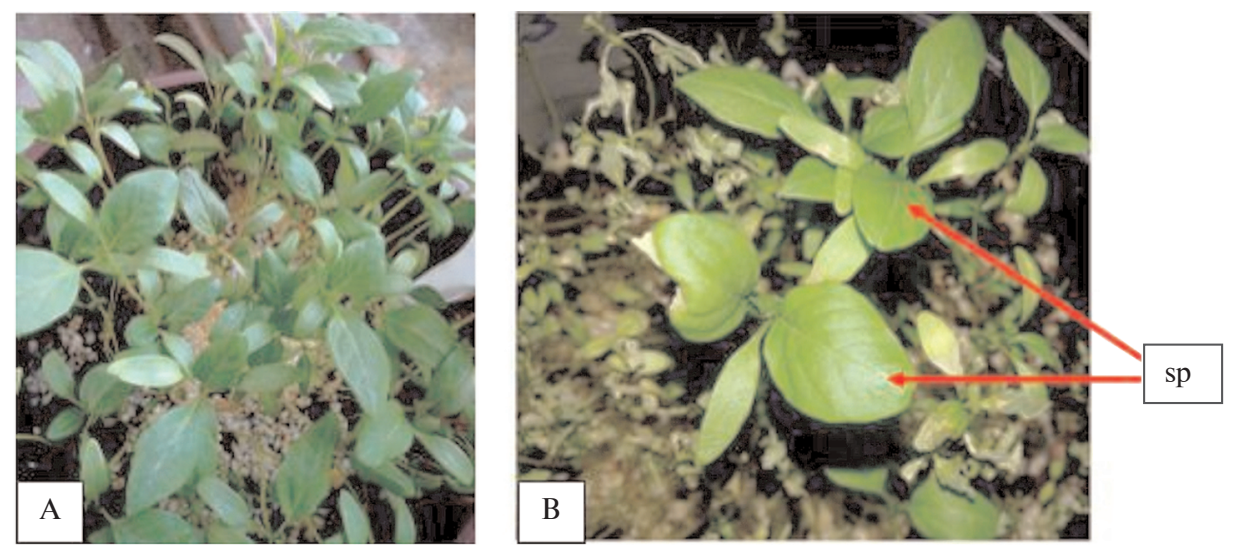

Fig. 4. The effect of herbicide on presumably transformed seedlings of Amaranthus caudatus, cv. Helios: A - plants before spraying with herbicide; B - plants at 7 th day after spraying with herbicide (160 mg/l); sp - seedlings, which survived

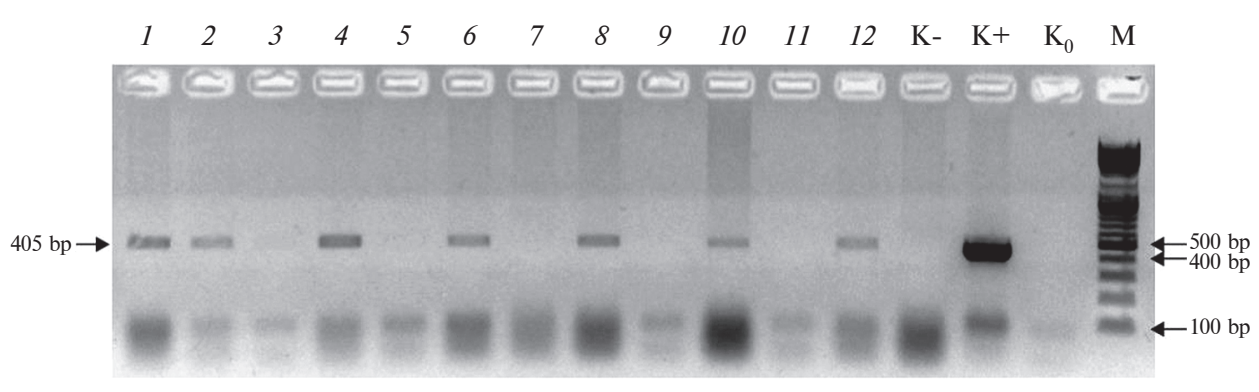

Fig. 5. PCR analysis of amaranth plants using bar3F and bar4R primers for the bar gene: lanes $1-12-$ total DNA of experimental samples $(1,11-12-\mathrm{cv}$. Karmin, 2-10 - cv. Helios; 1 - sample with vector pCB131, 2 - sample with vector pICH5290, 3-12 - samples with vector $\mathrm{pCB125)}$; $\mathrm{K}-\mathrm{C}_{-}$negative control, DNA of non-transformed plants, $\mathrm{K}+-$ positive control, DNA of transgenic $N$. tabacum, $\mathrm{K}_{0}-$ no-DNA, M - Fisher Thermo Scientific GeneRuler ${ }^{\mathrm{TM}}$ DNA Ladder Mix; $405 \mathrm{bp}$ - the expected size of the amplicon, specifying bar gene in the leaf genomic DNA of expected transgenic lines; samples $1-2,4$, $6,8,10-12-$ bar positive plants

(160 mg/l) was $4.05 \%$ (81 plants of 2,000). The percentage of cv. Karmin plants (with vector pCB125) tolerant to the effect of the herbicide $(160 \mathrm{mg} / \mathrm{l})$ was $2.4 \%$ (48 plants of 2,000). The percentage of tolerant $A$. $\times$ caudatus cv. Karmin plants (with vector pCB131) was $0.6 \%$ (12 plants of 2,000).

Sometimes the main drawback of the transformation process is the unpredictability of the pattern of transgenes integration in the host genome and their expression. That is why, as the final step of the experiment, it was necessary to confirm the results with PCR analysis, as it is a more reliable method than herbicide selection alone.

PCR analysis. During the analysis of 130 samples of the tested $A$. × caudatus Helios and Karmin cultivars, the presence of DNA fragment with $405 \mathrm{bp}$ was detected. This confirms the presence of the bar gene in the transformed plant (Fig. 5). The percentage of bar-positive plants for cv. Helios (gene vector pCB125) was $0.6 \%$ of the total initial quantity of 
O.M. YAROSHKO, B.V. MORGUN, L.G. VELYKOZHON et al.

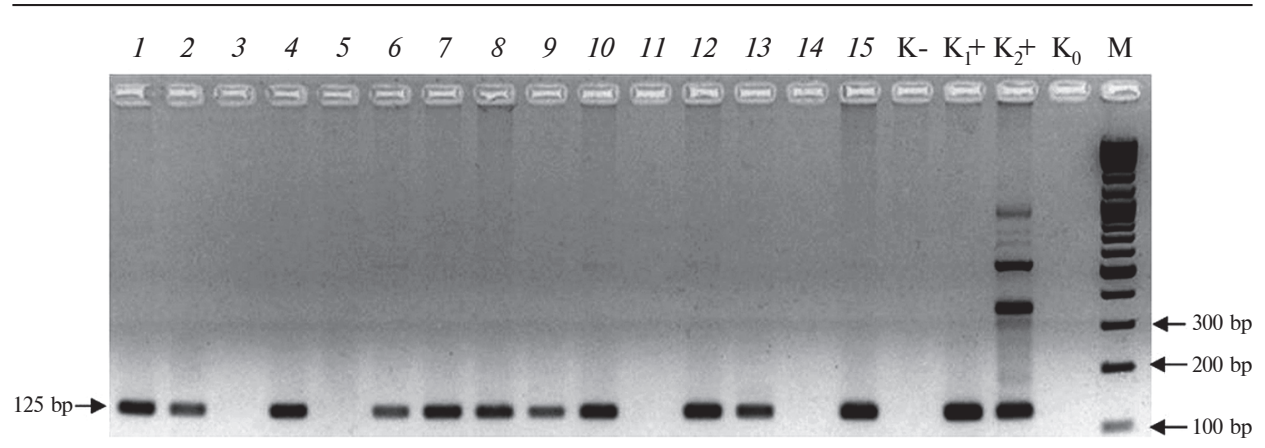

Fig. 6. PCR analysis of amaranth plants using primers U-NOS, D-NO for the nos terminator: lanes $1-15-$ total DNA of experimental samples $(1,11-15-\mathrm{cv}$. Karmin, 2-10cv. Helios; 1 - sample with vector pCB131, 2-15 - samples with vector pCB125); K- negative control, DNA of non-transformed plants; $\mathrm{K}_{1}+-$ positive control, plant DNA of transgenic $N$. tabacum; $\mathrm{K}_{2}+-$ DNA of $A$. tumefaciens subtype C58, $\mathrm{K}_{0}-$ no-DNA; M Fisher Thermo Scientific GeneRuler TM DNA Ladder Mix; $125 \mathrm{bp}$ - the expected size of the amplicon, specifying nos terminator in the leaf genomic DNA of expected transgenic lines; samples $1-2,4-6,8-10,15,17-18,21-$ NOS terminator positive plants

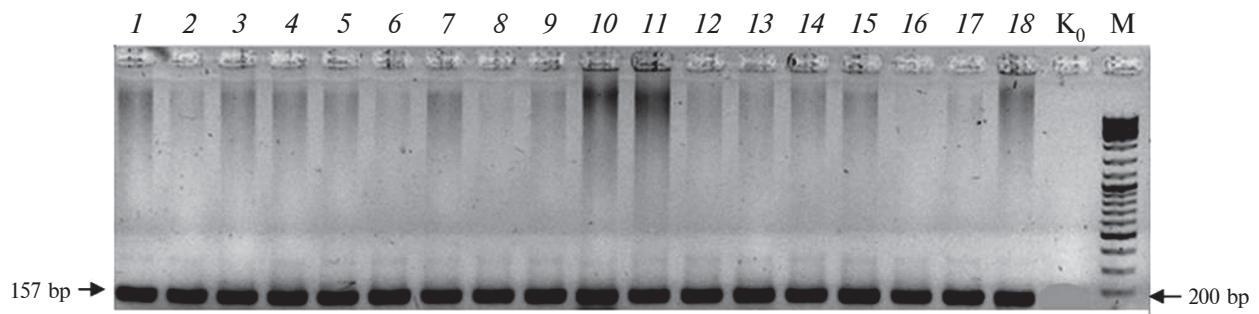

Fig. 7. PCR analysis of amaranth plants using primers tubF and tubR for the reference gene of $\beta$-tubulin: lanes $1-18-$ total DNA of experimental samples $(1,11-18-\mathrm{cv}$. Karmin, 2-10 - cv. Helios; 1, 2 - sample with vector pCB131, 3-18 - samples with vector pCB125); $\mathrm{K}_{0}-$ no-DNA; $\mathrm{M}-$ Fisher Thermo Scientific GeneRuler ${ }^{\mathrm{TM}}$ DNA Ladder Mix; $157 \mathrm{bp}$ - the expected size of the amplicon, specifying the $\beta$-tubulin gene in the leaf genomic DNA of expected transgenic lines; samples $1-18-\beta$-tubulin positive plants

plants (12 plants of 2,000) and for cv. Karmin (gene vector pCB131) was $0.1 \%$ of the total initial quantity of plants (2 plants of 2,000).

Also, the presence of a DNA fragment with 125 bp was detected. This confirms the presence of the nos terminator sequence in the transformed plant (Fig. 6). The percentage of nos terminator-positive plants for cv. Helios was $0.15 \%$ of the total initial quantity of plants (3 plants of 2,000).

The presence of DNA fragment $157 \mathrm{bp}$ long was detected. This confirms the presence of the $\beta$-tubulin gene in the transformed plant (Fig. 7). The percentage of $\beta$-tubulin-positive plants for cultivars of $A . \times$ caudatus was $100 \%$. $\beta$-tubulin is reference gene. Reference genes are used in PCR reactions as indicators of quality and quantity of extracted DNA. The reference gene is detected by PCR, even if it is present in one copy. A positive PCR reaction on the reference gene indicates that the quantity and quality of the isolated DNA is sufficient for further PCR reactions on the presence of other genes.

No presence of DNA fragment with 720 bp was detected. This confirms that plants did not contain the vir $C$ gene and means that there was no live Agrobacterium in the plant tissues (Fig. 8). 
PCR ANALYSES OF FIRST-GENERATION PLANTS OF AMARANTHUS CAUDATUS L.

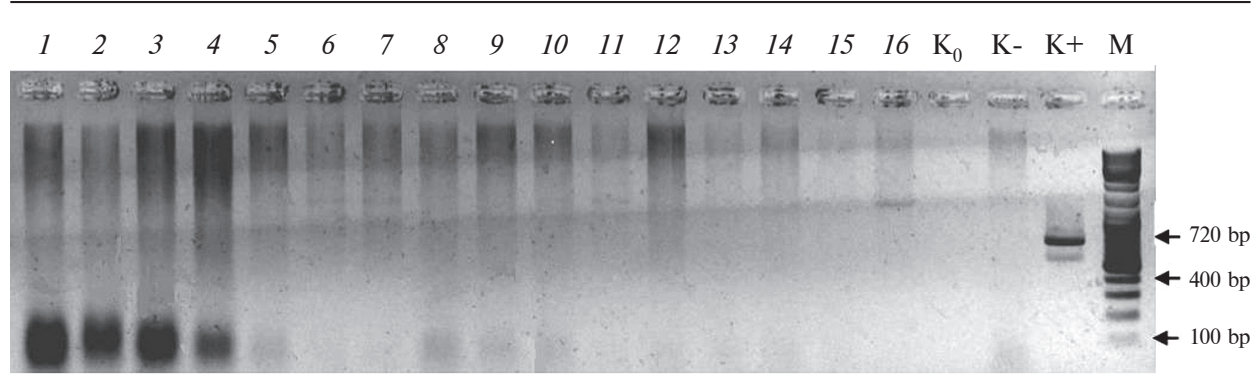

Fig. 8. PCR analysis of amaranth plants using primers Vir CF, Vir CR for the reference gene of vir $C$ : lanes 1-16 - total DNA of experimental samples $(1,11-16-\mathrm{cv}$. Karmin, 210 - cv. Helios; 1, 2- sample with vector pCB131, 3-16- samples with vector pCB125); $\mathrm{K}_{0}-$ no-DNA; $\mathrm{K}^{-}-$DNA of non-transformed plants; $\mathrm{K}^{+}-$total DNA of $A$. tumefaciens subtype C58; M - Thermo Fisher Scientific GeneRuler' ${ }^{\mathrm{TM}}$ DNA Ladder Mix; 720 bp - the expected size of the amplicon, specifying vir $C$ gene in the leaf genomic DNA of the expected transgenic lines; samples $1-16-\operatorname{vir} C$-negative plants

Initial experiments concerned with the transformation of amaranth species using Agrobacterium strains were unsuccessful [22]. At present, there exists a proof that it is possible to obtain transgenic amaranth plants with A. rhizogenes and A. tumefaciens. However, there are relatively few works dealing with the transformation of amaranth. Positive results were obtained in transforming $A$. tricolor L. [3] and A. spinosus L. [4] using wild strains of Agrobacterium rhizogenesis A 4. The authors obtained transgenic roots.

Positive results were obtained in the transformation of amaranth species with strains of Agrobacterium tumefaciens. There were obtained transgenic plants of A. hypochondriacus L., cv. Azteca using an Agrobacterium vector with marker genes [5]. Transgenic A. tricolor L. was obtained by two different groups of scientists [6, 23], a vector with marker genes was used in [6].

In addition, there are two studies dedicated to the transformation through amaranth inflorescence. Munusamy et al. [24] used the vector with selective genes, and Taipova [7] conducted experiments with $A$. retroflexus, A. viridis, A. cruentus. Both works asserted that positive and promising results were achieved and that transgenic seeds were obtained. However, their results do not seem convincing. Munusamy et al. [24] did not indicate the species of the amaranth they worked with, while Taipova [7] did not specify the types of bacteria used. The results of the biochemical and genetic analyses, on the basis of which it would be possible to state with accuracy that they obtained transgenic seeds, are not shown.

In our experiments, the frequency of amaranth transformation by the «floral-dip» method was quite similar compared to that obtained for Arabidopsis thaliana. Frequency of transformation for Arabidopsis was in the range of $0.5 \%$ to $3 \%$ [14].

The «floral-dip» method is used as an alternative to Agrobacteriummediated transformation in those cases where, for whatever reason, the latter cannot be performed in the laboratory. There may be various possible explanations. One is the presence of biochemical compounds in plant tissues that have strong antibacterial properties and inhibit the growth of agrobacteria at the initial stages of transformation. Second is the small amount of regeneration or its complete absence in plants (in our case, 
amaranth is characterized by the presence of high levels of auxins in tissues, which complicates the formation of both additional lateral buds and regenerants). Third is the possible high degree of contamination of the original plant material with fungal agents.

The floral-dip method of plant transformation is quite simple and less expensive than the Agrobacterium-mediated transformation of plants under sterile conditions. This is because it does not require the presence of a laminar box, large amounts of sterile laboratory glassware, or a culture conditions of thermal room for growing plants in vitro.

Nevertheless, when applying the floral-dip method, difficulties may arise at the stage of screening potentially transformed plants. It is not always possible to select only transformed plants using a herbicide. The effective dose of herbicide for screening potentially transformed plants should be first accurately determined on non-transformed plants. It should also be considered that resistance to the action of herbicide may appear in non-transformed plants as a result of spontaneous mutations. This can also give a false positive result. It is therefore necessary to use several different screening methods when selecting transformed plants after transformation by the «floral-dip» method.

It is essential to check for the presence of transferred genes in plants using molecular-genetic methods (i.e. PCR analysis and electrophoresis). After transformation by the «floral-dip» method, the plants are not treated with special sterilizing agents, so it is likely that living bacteria can survive in the seeds of the $T_{0}$ and in the tissues of the $T_{1}$ generations of plants. Due to the possible presence of agrobacterial contamination in $T_{1}$ plant tissues, it is necessary additionally to check for the presence of the vir $C$ or vir $D$ bacteria genes by PCR analysis and electrophoresis, in order to avoid false positive results. Also, the plants should be checked for the presence of target components that should begin to be synthesized by the plant after the effective insertion of the transferred genes. Additionally, if laboratory operating conditions permit, a check should be carried out for the presence of transferred genes in plant tissues using Southern-blot analysis. Scientists should weigh all the advantages and disadvantages before choosing the most suitable transformation method.

So, in our experiments the transfer of T-DNA sequence of pCB125 vector from Agrobacterium tumefaciens and pCB131 vector from A. rhizogenes was evaluated in the first generation amaranth plants. Seeds of the Helios and Karmin amaranth cultivars were obtained after treatment with A. tumefaciens and A. rhizogenes by the «floral-dip» method.

After spraying with the herbicide, tolerant plants were obtained for both cultivars: Helios and Karmin. The percentage of $A . \times$ caudatus cv. Helios (vector pCB125) plants tolerant to the herbicide effect $(160 \mathrm{mg} / \mathrm{l})$ was $4.05 \%$ (81 plants of 2,000), cv. Karmin (vector pCB125) - $2.4 \%$ (48 plants of 2,000). The percentage of tolerant $A$. $\times$ caudatus cv. Karmin (vector pCB131) plants was $0.6 \%$ (12 plants of 2,000).

The presence of foreign genes in amaranth tissue was proved with PCR analyses. The positive results were obtained for both cultivars. The percentage of bar-positive plants was $0.6 \%$ (cv. Helios, gene vector $\mathrm{pCB} 125$ ) and $0.1 \%$ (cv. Karmin, gene vector pCB131) of the total initial quantity of plants. The percentage of nos terminator-positive plants for 
cv. Helios was $0.15 \%$ out of the total initial quantity of plants. The presence of a DNA fragment with $157 \mathrm{bp}$ was identified.

\section{REFERENCES}

1. Biswas, M., Das, S.S. \& Dey, S. (2013). Establishment of a stable Amaranthus tricolor callus line for production of food colorant. Food Sci. Biotechnol., 22, No. 1, pp. 1-8.

2. Yaacob, J.S., Hwei, L.C. \& Taha, R.M. (2012). Pigment analysis and tissue culture of Amaranthus cruentus L. Acta Horticult., 958, pp. 171-178. https://doi.org/ 10.17660/ActaHortic.2012.958.20

3. Swain, S.S., Sahu, L., Barik, D.P. \& Chand, P.K. (2010). Agrobacterium $\times$ plant factors influencing transformation of 'Joseph's coat' (Amaranthus tricolor L.). Scientia Horticult., 125 (3), pp. 461-468. https://doi.org/10.1016/j.scienta.2010.04.034

4. Pal, A., Swain, S.S., Mukherjee, A.K. \& Chand, P.K. (2013). Agrobacterium pRi TL-DNA rolB and TR-DNA Opine Genes Transferred to the Spiny Amaranth (Amaranthus spinosus L.) - a Nutraceutical Crop. Food Technol. and Biotechnol., 51 (1), pp. 26-35.

5. Jofre-Garfias, A.E., Villegas-Sepulveda, N., Cabrera-Ponce, J.L., Adame-Alvarez, R.M., Herrera-Estrella, L. \& Simpson, J. (1997). Agrobacterium mediated transformation of Amaranthus hypochondriacus: light- and tissue-specific expression of a pea chlorophyll a/b-binding protein promoter. Plant Cell Reports, 16, pp. 847-52.

6. Pal, A., Swain, S., Das, A.B., Mukherjee, A.K. \& Chand, P.K. (2013). Stable germ line transformation of a leafy vegetable crop amaranth (Amaranthus tricolor L.) mediated by Agrobacterium tumefaciens. In Vitro Cellular \& Developmental Biology-Plant, 49 (2), pp. 114-28.

7. Taipova, R.M. \& Kuluev, B.R. (2015). Amaranth features of culture, prospects of cultivation in Russia and generation of transgenic Russian varieties. Biomica, 7 (4), pp. 28499.

8. Yaroshko, O.M. \& Kuchuk, M.V. (2018). Agrobacterium-caused transformation of cultivars Amaranthus caudatus L. and hybrids of A. caudatus L. $\times$ A. paniculatus. Int. J. of Secondary Metabolite, 5(4), pp. 312-318. https://doi.org/10.21448/ijsm.478267

9. Yaroshko, O., Vasylenko, M., Gajdošova, A., Morgun, B., Khrystan, O., Velykozhon, L. \& Kuchuk M. (2019). «Floral-dip» transformation of Amaranthus caudatus L. and hybrids A. caudatus $\times$ A. paniculatus L. Biologija, 64, No. 4, pp. 321-330. https://doi.org/10.6001/biologija.v64i4.3904

10. State Register of Plant Varieties Suitable for Dissemination in Ukraine in 2019 (2019). Kyiv, p. 289.

11. Doroshenko, O. (2017). Amaranth field germination in the conditions of the western Forest-Steppe. Aktualni Pytannia Suchasnykh Tekhnolohii Vyroshchuvannia Silskohospodarskykh Kultur V Umovakh Zmin Klimatu. Zbirnyk naukovykh prats vseukr. nauk.-prakt. konferentsiia (15-16 chervnia 2017. Kamianets-Podilskyi). Ternopil Krok, pp. 78-80 [in Ukrainian].

12. Zhang, X., Henriques, R., Lin, S.S., Niu, Q. \& Chua, N.H. (2006). Agrobacterium mediated transformation of Arabidopsis thaliana using the floral dip method. Nature Protocols, 1 (2), pp. 641-646.

13. Curtis, I.S. (2004). Protocols of transgenic crops by floral-dip method. Methods in Mol. Biol., 286, pp. 103-109.

14. Clough, S.J. \& Bent, A.F. (1998). Floral dip: A simplified method for Agrobacteriummediated transformation of Arabidopsis thaliana. Plant J., 16, pp. 735-43.

15. Stewart, C.N. \& Via, L.E. (1993). A rapid CTAB DNA isolation technique useful for RAPD fingerprinting and other PCR applications. Biotechniques, 14 (5), pp. 748-50.

16. Nitovska, I.O., Abraimova, O.Ye., Satarova, T.M., Shakhovskyi, A.M. \& Morhun, B.V. (2014). Biollistics transformation of immature maize embryos. Faktory eksperymentalnoi evoliutsii orhanizmiv. Zbirnyk naukovykh prats za red. Kunakha V.A., 15, pp. 112-117 [in Ukrainian].

17. James, D., Schmidt, A.-M., Wall, E., Green, M. \& Masri, S. (2003). Reliable detection and identification of genetically modified maize, soybean, and canola by multiplex PCR analysis. J. Agric. Food Chem., 51 (20), pp. 5829-5834. https://doi.org/ $10.1021 / \mathrm{jf0341159}$ 
18. Godar, A.S., Varanasi, V.K., Nakka, S., Prasad, P.V., Thompson, C.R. \& Mithila, J. (2015). Physiological and Molecular Mechanisms of Differential Sensitivity of Palmer Amaranth (Amaranthus palmeri) to Mesotrione at Varying Growth Temperatures. PLOS One, 19, 10 (5), p. e0126731. https://doi.org/10.1371/journal.pone.0126731

19. Parminder, S. Chahal, Vijay, K. Varanasi, Jugulam, M. \& Jhala, A.J. (2017). Glyphosate-resistant palmer amaranth (Amaranthus palmeri) in Nebraska: confirmation, EPSPS gene amplification, and response to POST corn and soybean herbicides. Weed Technol., 31, pp. 80-93. https://doi.org/10.1614/WT-D-16-00109.1

20. Sawada, H., Ieki, H. \& Matsuda, I. (1995). PCR detection of Ti and Ri Plasmids from phytopathogenic Agrobacterium strains. Applied and Environmental Microbiology, 61 (2), pp. 828-831.

21. Harrison, S.J., Mott, E.K., Parsley, K., Aspinall, S., Gray, J.C. \& Cottage, A. (2006). A rapid and robust method of identifying transformed Arabidopsis thaliana seedlings following floral dip transformation. Plant Methods, 2, pp. 1-7. https://doi.org/10.1186/17464811-2-19

22. De Cleene, M. \& De Ley, J. (1976). The host range of Crown Gall. The Botanical Review, 42, pp. 389-466.

23. Swain, S.S., Sahu, L., Barik, D.P. \& Chand, P.K. (2009). Genetic transformation of Amaranthus tricolor L. using Ri plasmid vectors. In: Bastia AK and Mohapatra UB (eds.) Recent trends in monitoring and bioremediation of mine and industrial environment. North Orissa University: Orissa.

24. Munusamy, U., Abdullah, S., Aziz, M. \& Khazaai, H. (2013). Female reproductive system of Amaranthus as the target for Agrobacterium-mediated transformation. Advances in Bioscience and Biotechnology, 4, pp.188-192.

Received 02.03.2020

\title{
АНАЛІЗИ ПЛР РОСЛИН ПЕРШОГО ПОКОЛЇННЯ AMARANTHUS CAUDATUS L. ПІСЛЯ ГЕНЕТИЧНОЇ ТРАНСФОРМАЦІї МЕТОДОМ «FLORAL-DIP»
}

\author{
О.М. Ярошко ${ }^{1}$ Б.В. Моргун ${ }^{1,2}$, Л.Г. Великожон ${ }^{1,2}$, А. Гайдошова $^{3}$, О.Л. Андрущенко \\ M.В. Кучук ${ }^{1}$
}

${ }^{1}$ Їнститут клітинної біології і генетичної інженерії Національної академії наук України

03143 Київ, вул. Академіка Заболотного, 148

90tigeryaroshko90@gmail.com

${ }^{2}$ Інститут фізіології рослин и генетики Національної академії наук України

03022 Київ, вул. Васильківська, 31/17

3ذँнститут генетики рослин і біотехнології Академії наук Словаччини

95007, Нітра, вул. Академіцка, 2

${ }^{4}$ Національний ботанічний сад ім. М.М. Гришка Національної академії наук України 01014 Київ, вул. Тимірязєвська, 1

Амарант - $\mathrm{C}_{4}$-рослина, яка використовується в різних галузях промисловості і $є$ перспективним об’єктом для генетичної трансформації. Після «floral-dip» трансформації сортів Helios i Karmin A. caudatus L. 3 використанням штаму Agrobacterium rhizogenes A4 і штаму Agrobacterium tumefaciens GV3101 були отримані трансформовані рослини першого покоління. Вектори рСВ125 і рСВ131 містять ген bar, що надає стійкості до Basta (комерційний гербіцид). Насіння сортів амаранту Karmin i Helios було отримано після обробки суспензією, що містить $A$. tumefaciens і A. rhizogenes методом «floral-dip» («занурення квіткових суцвіть»). Перенесення генного вектора рСВ131 штамом Agrobacterium rhizogenes A4 і генного вектора рСВ125 штамом Agrobacterium tumefaciens GV3101 оцінювали шляхом відбору стійких рослин амаранту після обробки гербіцидом. Після обприскування гербіцидом, були отримані стійкі рослини двох сортів: Helios i Karmin. Відсоткова частка рослин $A$. $\times$ caudatus copту Helios (з вектором рСВ125), толерантних до дії гербіциду (концентрація 160 мг/л), становила 4,05\%, сорту Karmin (з вектором рСВ125) $-2,4 \%$. Відсоток стійких рослин $A$. $\times$ caudatus 
сорту Karmin (з вектором рСВ131) становив 0,6\%. Було проаналізовано присутність генів вектора рCB125 (штам A. tumefaciens GV3101) і генів вектора рCB131 (штам Agrobacterium rhizogenes A4) в тканинах амаранту. Їнтеграція і транскрипція гена bar і nos-термінатора в рослинах була підтверджена результатами аналізу ПЛР. Відсоток bar-позитивних від загальної початкової кількості рослин становив 0,6 \% для сорту Helios, генетичний вектор pCB125 (12 рослин із 2000) і 0,1 \% для сорту Karmin, генетичний вектор рСВ131 (2 рослин із 2000). Відсоток поs-термінатор-позитивних рослин для сорту Helios становив 0,15 \% від загальної початкової кількості рослин (3 рослини із 2000).

Ключові слова: Amaranthus, Agrobacterium, трансформація, генетично модифіковані рослини. 